\title{
Nitrogen Test Tool in Rice Leaves Based on Android Application
}

\section{Alat Uji Kandungan Nitrogen dalam Daun Padi Berbasis Aplikasi Android}

\author{
Muhamad Darso, Anton Yudhana \\ Program Studi Teknik Elektro, Universitas Ahmad Dahlan, Yogyakarta, Indonesia
}

\section{INFORMASI ARTIKEL}

\section{Riwayat Artikel:}

Dikirimkan 06 November 2020, Direvisi 06 Januari 2021,

Diterima 08 Januari 2021.

\section{Kata Kunci:}

Aplikasi;

Nitrogen;

Padi;

Android;

Daun Padi.

\section{Penulis Korespondensi:}

Muhamad Darso, Program Studi Teknik elektro, Universitas Ahmad Dahlan.

Kampus IV, Jln. Ringroad Selatan, Kragilan, Tamanan, Banguntapan, Bantul, Yogyakarta 55191 Surel/Email: darsomuhamad@gmail.com

\begin{abstract}
ABSTRAK
This study aims to make an application for measuring nitrogen requirements in rice leaves based on an android application. The method used is the On Touch Motion Event. The onTouch method will be used when a touch will be sent to be displayed, then MotionEvent contains information about the touch made. System testing is carried out to display images using the Open Camera button using a smartphone camera, after that look for the $R G B$ value then convert it to the BWD scale. This research has succeeded in building an application that can determine nitrogen levels in rice leaves through leaf color and provide recommendations for the amount of fertilization according to the desired results. The results of tests that have been carried out on 6 samples of rice leaves with 60 samples of $R G B$ value data produce an accuracy rate of using the application of $78.33 \%$ and the remaining $21.66 \%$ is an error value. And how to calculate the land area, the results obtained from the need for urea per plant in 1 ha are $120 \mathrm{~kg}$, where the BWD table shows the value of leaf color on a scale of 2-3 and requires a urea measurement of 100 which is estimated to get a yield rate of $6 \mathrm{t} / \mathrm{ha}$.
\end{abstract}

Penelitian ini bertujuan membuat aplikasi pengukuran kebutuhan nitrogen dalam daun padi berbasis aplikasi android. Metode yang digunakan adalah $O n$ Touch Motion Event. Metode onTouch akan digunakan ketika sebuah sentuhan akan dikirim untuk ditampilkan, kemudian MotionEvent berisi tentang informasi tentang sentuhan yang dilakukan. Pengujian system yang dilakukan untuk menampilkan citra menggunakan tombol Buka Kamera menggunakan kamera smartphone, setelah itu mencari nilai RGB kemudian dikonversikan ke dalam skala BWD. Penelitian ini telah berhasil membangun aplikasi yang dapat mengetahui kadar nitrogen pada daun padi melalui warna daun dan memberikan rekomendasi banyaknya pemupukan sesuai dengan hasil yang ingin dicapai. Hasil pengujian yang telah dilakukan pada 6 sampel daun padi dengan 60 sampel data nilai RGB menghasilkan tingkat akurasi menggunakan aplikasi sebesar 78,33\% dan 21,66\% sisanya merupakan nilai error. Dan cara menghitung luas lahan diperoleh hasil kebutuhan urea per tanaman dalam 1 ha adalah $120 \mathrm{~kg}$ dimana dalam tabel BWD menunjukkan nilai warna daun berada pada skala 2-3 dan membutuhkan takaran urea 100 yang diperkirakan mendapatkan tingkat hasil $6 \mathrm{t} / \mathrm{ha}$.

This work is licensed under a Creative Commons Attribution-Share Alike 4.0

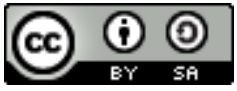

\section{Sitasi Dokumen ini:}

M. Darso and A. Yudhana, "Nitrogen Test Tool in Rice Leaves Based on Android Application," Buletin Ilmiah Sarjana Teknik Elektro, vol. 1, no. 3, pp. 62-71, 2021. DOI: 10.12928/biste.v3i1.3071 


\section{PENDAHULUAN}

Tanaman padi merupakan tanaman pangan sebagai sumber energi yang umumnya dikonsumsi masyarakat Indonesia. Hampir separuh penduduk dunia, terutama di Asia menggantungkan hidupnya dari tanaman padi [1]. Tingginya hasil produksi padi dipengaruhi oleh penyerapan unsur hara seperti Nitrogen, Fosfor dan Kalium sehingga penting untuk mengetahui serapan nitrogen sebagai salah satu unsur hara dalam pertumbuhan tanaman padi [2].

Nitrogen (N) merupakan unsur hara yang paling penting. Kebutuhan tanaman akan N lebih tinggi dibandingkan dengan unsur hara lainnya, selain itu $\mathrm{N}$ merupakan faktor pembatas bagi produktivitas tanaman [3]. Pertumbuhan tanaman yang baik dan hasil yang tinggi membutuhkan suplai nitrogen $(\mathrm{N})$ yang cukup, bila suplai $\mathrm{N}$ tak cukup tanaman akan mengalami kekurangan $\mathrm{N}$, yang ditunjukkan oleh pertumbuhan organ dan keseluruhan tanaman yang tidak normal [4].

Efisiensi penggunaan hara pupuk adalah bagian yang sangat penting dalam sistem pertanian padi intensif. Sistem ini di samping menghasilkan efisiensi agronomi, juga dapat meningkatkan efisiensi ekonomis dan memberi dampak positif bagi kesehatan lingkungan (karena penggunaan hara/pupuk menjadi lebih rasional dan terkendali) [5]. Pemberian pupuk $\mathrm{N}$ yang berlebihan ini menyebabkan efisiensi pupuk menurun serta membahayakan tanaman dan lingkungan [6]. Kebutuhan dan efisiensi pupuk ditentukan oleh dua faktor utama yang saling berkaitan, yaitu (a) ketersediaan hara dalam tanah, termasuk pasokan hara melalui air irigasi dan sumber lainnya, dan (b) kebutuhan hara tanaman [7].

Warna daun adalah suatu indikator yang berguna bagi kebutuhan pupuk $\mathrm{N}$ tanaman padi. Daun yang berwarna pucat atau hijau kekuningan menunjukkan bahwa tanaman kekurangan N [8]. Bagan Warna Daun dapat digunakan untuk menentukan dosis dan waktu pemberian pupuk $\mathrm{N}$ yang lebih tepat [7]. Waktu penggunaan BWD dapat dengan dua cara, yaitu: 1) berdasarkan kebutuhan tanaman, yaitu dengan membandingkan warna daun padi dengan skala warna pada BWD dan 2) berdasarkan waktu yang telah ditetapkan, yaitu pada saat pembentukan anakan aktif (21-28 HST) dan primordial (35-40 HST) [9].

Penelitian yang dilakukan oleh peneliti sebelumnya [10] telah berhasil membangun sebuah sistem pendeteksian pra-panen padi berdasarkan warna daun dengan menggunakan pendekatan LVQ dan mampu membantu petani terutama untuk petani pemula dalam mendeteksi waktu panen padi. Sistem memiliki akurasi sebesar $55 \%$ untuk pengujian data training, dan $50 \%$ untuk pengujian data testing.

Berdasarkan pada latar belakang dan penelitain sebelumnya [11][12][13], penelitian ini akan membangun sebuah aplikasi alat uji kandungan nitrogen dalam daun padi berbasis aplikasi android. Diharapkan dengan aplikasi tersebut dapat membantu petani dalam memantau kondisi nitrogen tanamannya.

\section{METODE PENELITIAN}

Penelitian dilakukan pada bulan November 2019 dilaksanakan di lahan sawah di Kecamatan Srandakan, Kabupaten Bantul, Yogyakarta dan jenis padi yang diuji adalah padi Matonggang. Obyek citra yang digunakan adalah 6 daun padi dari rumpun yang berbeda dalam 1 petak sawah. Setiap 1 citra daun akan diambil 10 sampel nilai RGB sehingga total sampel nilai RGB yang akan digunakan dalam penelitian ini adalah 60 sampel. Pengukuran manual menggunakan alat Bagan Warna Daun [14] dan menggunakan aplikasi Alat Uji Kandungan Nitrogen Dalam Daun Padi. Penelitian ini menggunakan Android Studio 3.0.1, ADT, dan JDK (Java Development Kit).

\subsection{PERANCANGAN APLIKASI}

Diagram blok rancangan aplikasi Alat Uji Kandungan Nitrogen Dalam Daun padi yang dibangun disajikan pada Gambar 1. Pertama-tama menentukan objek padi dahulu kemudian menggunakan kamera smartphone untuk mendapatkan hasil citra dari daun padi kemudian akan terbaca oleh software untuk menentukan nilai RGB berdasarkan citra yang di dapat lalu mendapatkan hasil dari foto daun padi dan mendapat nilai skala berdasarkan tabel BWD dan langkah terakhir mengetahui banyak pupuk yang akan dibutuhkan berdasarkan hasil dari perhitungan dan pembacaan sistem.

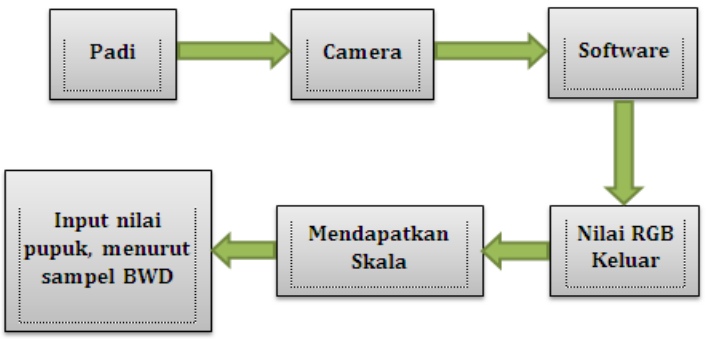

Gambar 1. Diagram blok sistem aplikasi pengukuran kebutuhan nitrogen pada daun padi 
Dari Gambar 1 tersebut dapat diketahui bahwa aplikasi pengukuran kebutuhan nitrogen pada daun padi dapat diperoleh dengan proses pengambilan citra daun padi melalui kamera android. Gambar 1 dapat dijelaskan bahwa pengambilan citra daun dengan cara daun difoto menggunakan fitur kamera yang ada pada android setelah diperoleh citra daun padi kemudian diolah ke dalam aplikasi pengukur nitrogen dan akan mendapatkan hasil nilai RGB dari daun padi tersebut dan akan menampilkan kebutuhan nitrogen atau pemupukan padi dalam satuan $\mathrm{kg} / \mathrm{ha}$.

\subsection{ALGORITMA}

Hal yang perlu dilakukan terlebih dahulu sebelum membuat program adalah membuat diagram alir (flowchart) sebagai panduan penulisan program. Flowchart dapat dilihat pada Gambar 2. Pada penelitian ini akan dihitung kebutuhan nitrogen salah satunya dengan mengambil citra daun padi menggunakan kamera smartphone. Proses untuk menghitung kebutuhan nitrogen dimulai dengan menangkap citra dari sample daun padi yang menggunakan kamera smartphone melalui fitur kamera pada aplikasi Pengukuran Kebutuhan Nitrogen Pada Daun Padi. Bisa juga menggunakan fitur galeri yang ada pada smartphone, dengan cara smartphone sudah menyimpan foto sempel terlebih dahulu. Setelah citra didapatkan, maka proses selanjutnya dilakukan untuk mendapatkan nilai RGB, kemudian dari nilai RGB yang sudah didapatkan digolongkan termasuk dalam skala yang akan ditentukan dalam metode BWD. Metode BWD digolongkan dalam 4 skala yaitu skala 2 sampai skala 5 dan aplikasi akan menampilkan jumlah pupuk urea yang dianjurkan dalam satuan $\mathrm{kg} / \mathrm{ha}$.

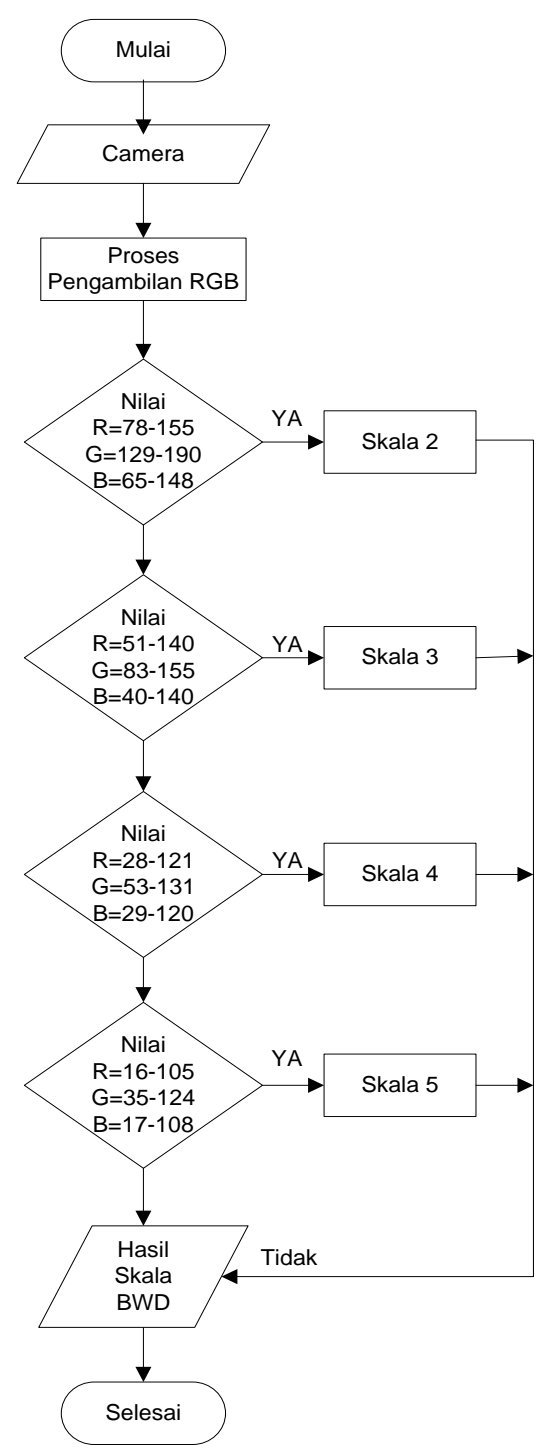

Gambar 2. Flowchart Proses perhitungan kebutuhan nitrogen 


\subsection{CARA KERJA APLIKASI}

Proses kerja dari aplikasi ini dimulai dengan menjalankan aplikasi, kemudian mengambil citra daun padi menggunakan kamera dan menampilkan citra daun padi yang telah diambil. Selanjutnya dalam proses pengambilan nilai RGB dilakukan dengan mengetuk pada citra padi. Prosedur yang digunakan dalam penelitian ini adalah prosedur OnTouch dan MotionEvent.

Prosedur OnTouch digunakan ketika akan menampilkan sentuhan, lalu MotionEvent akan mendapatkan titik koordinat dari sentuhan dan menggunakan fitur getPixel untuk mendapatkan nilai piksel yang dimiliki oleh citra, sehingga nilai RGB pada dot piksel merupakan nilai RGB yang akan digunakan. Setiap satu citra daun padi akan diambil 10 sampel nilai RGB, sehingga dari 6 citra daun akan mendapatkan 60 sampel nilai RGB. Kemudian dari nilai RGB tersebut akan digolongkan dalam skala berapa dalam metode BWD. Ada 4 indeks skala dalam metode BWD yaitu skala 2, skala 3, skala 4 dan skala 5. Tiap skala memiliki rekomendasi takaran pupuk tersendiri.

Tahap terakhir adalah menampilkan hasil akhir berupa nilai RGB yang telah diambil, kemudian nilai Skala BWD dan rekomendasi penggunaan pupuk sesuai dengan Skala BWD.

\section{HASIL DAN PEMBAHASAN}

Pada bagian ini, dijelaskan hasil penelitian dan diberikan diskusi yang komprehensif. Hasil disajikan dalam angka, grafik, tabel, dan lainnya yang membuat pembaca mengerti dengan mudah.

\subsection{Pengujian Sistem}

Pengujian kali ini dilakukan untuk mengetahui apakah aplikasi yang dibuat dapat dijalankan dengan baik dan tombol-tombol yang ada dapat bekerja sesuai dengan yang diharapkan. Dengan melakukan pengujian alat pada daun padi yang ada disawah langsung, serta dilakukan tidak hanya pada satu tanaman padi. Akan tetapi dilakukan pada tanaman padi yang berada pada sawah berbeda.

\subsection{Pengujian Tampilan GUI}

Pengujian system dilakukan menggunakan tampilan GUI setelah itu dilakukan pengecekan tampilan apakah tampilan GUI yang telah dirancang seperti letak judul/nama aplikasi, letak tombol-tombol sesuai dengan yang diinginkan. Setelah dirancang, tampilan GUI akan terlihat seperti pada Gambar 3 berikut.

\subsection{Pengujian Tombol Kamera}

Dalam aplikasi Alat Uji Kandungan Nitrogen Pada Tanaman Padi Berbasis Android ini terdapat 3 tombol yaitu, tombol Buka Kamera, tombol Petunjuk Penggunaan, dan tombol Tentang Aplikasi. Pertama tombol Buka Kamera yang menampilkan jendela baru dengan sebuah imageView untuk menampilkan gambar dua buah tombol yaitu tombol Ambil Gambar dan tombol Buka Gallery. Berikut perancangan fungsi tombol Buka Kamera, ketika tombol Buka Kamera ditekan, maka akan menampilkan sebuah jendela baru yang berisi sebuah imageView untuk menampilkan gambar/citra yang telah diambil dan dua buah tombol, yaitu tombol Ambil Gambar dan tombol Buka Gallery. Ketika tombol Ambil Gambar ditekan, akan membuka fitur kamera pada smartphone dan ketika tombol Buka Gallery ditekan maka akan membuka gallery untuk memilih gambar yang sudah tersimpan sebelumnya di dalam smartphone tersebut.

\subsection{Pengujian Tombol Petunjuk Penggunaan}

Tombol selanjutnya yaitu tombol Petunjuk Penggunaan, ketika tombol ini ditekan, maka akan menampilkan frame atau jendela baru dengan informasi tentang cara menggunakan aplikasi Pengukuran Kebutuhan Nitrogen Pada Tanaman Padi Berbasis Android. Berikut tampilan jendela petunjuk penggunaan aplikasi ditunjukkan pada Gambar 4.

Dari Gambar 4, system sudah bekerja dengan baik, dimana sistem bisa menampilkan intent yang berisi informasi cara menggunakan aplikasi Alat Uji Kandangan Nitrogen Pada Daun Padi Berbasis Android. Berikut rangcangan fungsi tombol Petunjuk Penggunaan, Tombol Petunjuk Penggunaan akan menampilkan jendela atau tab baru ketika ditekan dimana didalamnya terdapat petunjuk bagaimana cara menggunakan aplikasi ini ketika akan melakukan pengukuran duan padi.

\subsection{Pengujian Tombol Tentang Aplikasi}

Tombol ini berfungsi untuk menampilkan informasi tentang alat Uji Kandungan Kitrogen Pada Padi Berbasis dalam jendela baru. Berikut hasil pengujian tombol Tentang Aplikasi ditunjukan pada gambar 5. Dari gambar terlihat, sistem telah bekerja dengan baik, dimana sistem dapat menampilkan intent yang berisi tentang aplikasi Alat Uji Kandungan Nitrogen Pada Daun padi Berbasis Android. Ketika tombol Tentang aplikasi ditekan, maka muncul jendela baru mengenai informasi aplikasi yang telah dirancang. 


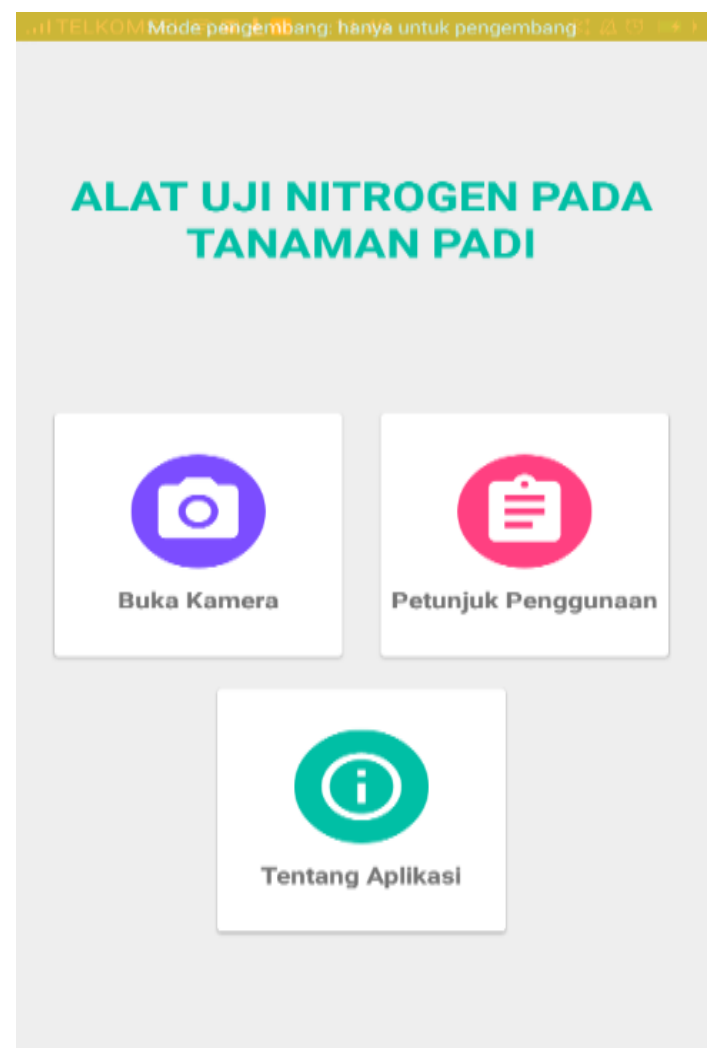

Gambar 3. Tampilan GUI halaman utama aplikasi Alat Uji Kandungan Nitrogen Pada Daun Padi Berbasis Android

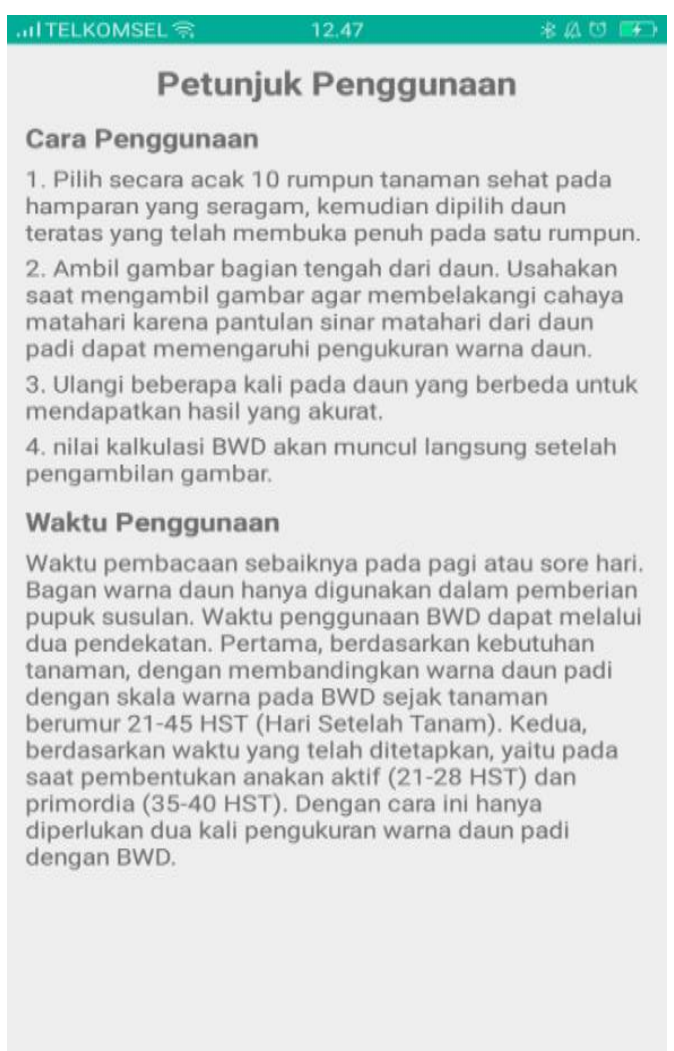

Gambar 4. Tampilan jendela petunjuk penggunaan aplikasi

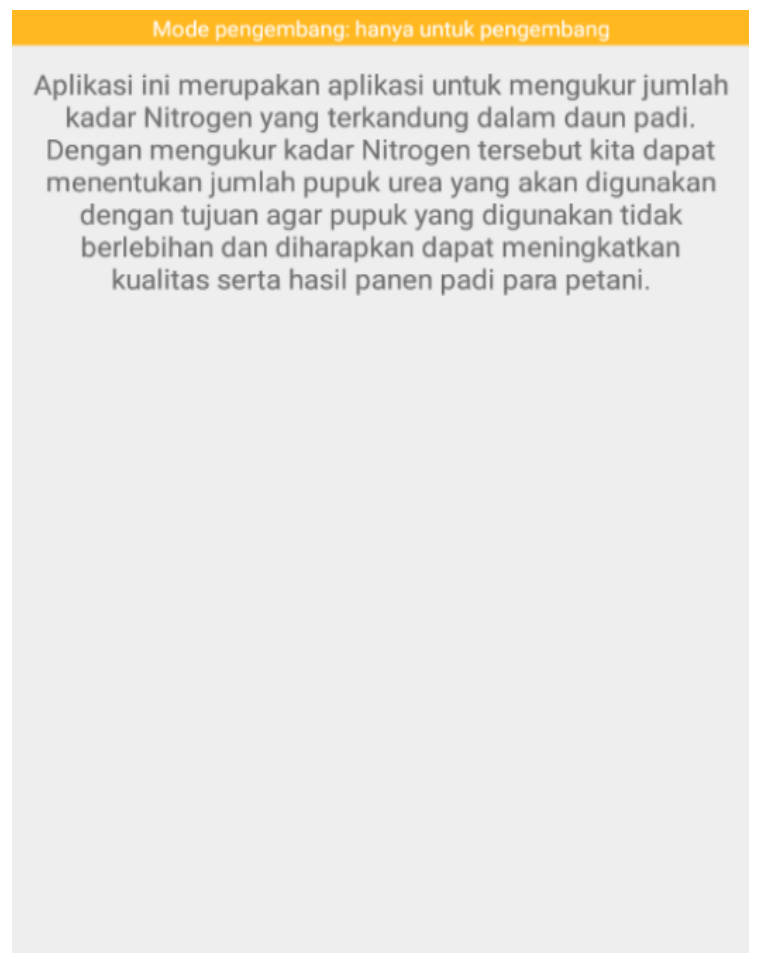

Gambar 5. Tampilan jendela informasi tentang aplikasi

\subsection{Pengujian Konversi ke Skala BWD}

Pengujian sistem yang dilakukan untuk menampilkan citra menggunakan tombol Buka Kamera menggunakan kamera smartphone, setelah itu mencari nilai RGB kemudian dikonversikan ke dalam skala 
BWD. Untuk memperoleh nilai RGB pada citra yang telah di ambil dapat dilakukan dengan menekan pada layar lalu akan menampilkan nilai RGB yang ada pada piksel tersebut, karena pada tahap ini menggunakan metode mition even action down dimana akan menampilkan nilai RGB yang dimiliki oleh pixsel yang di ketuk pada layar smartphone.

Pengujian pada sistem ini menggunakan rumpun padi secara acak, kemudi dipilih daun yang atas yang sudah terbuka secara penuh dalam satu rumpun. Langkah selanjutnya ambil citra daun padi tersebut menggunakan kamera smartphone dan ambil nilai RGB yang dimiliki daun tersebut dengan menekan pada layar. Dengan fitur motion event action down yang dimiliki oleh android studio kemudian akan mengambil nilai piksel yang dimiliki oleh citra dan akan menampilkan nilai RGB beserta dengan warnanya. Berikut gambar pengujian daun padi ditunjukkan pada Gambar 6.

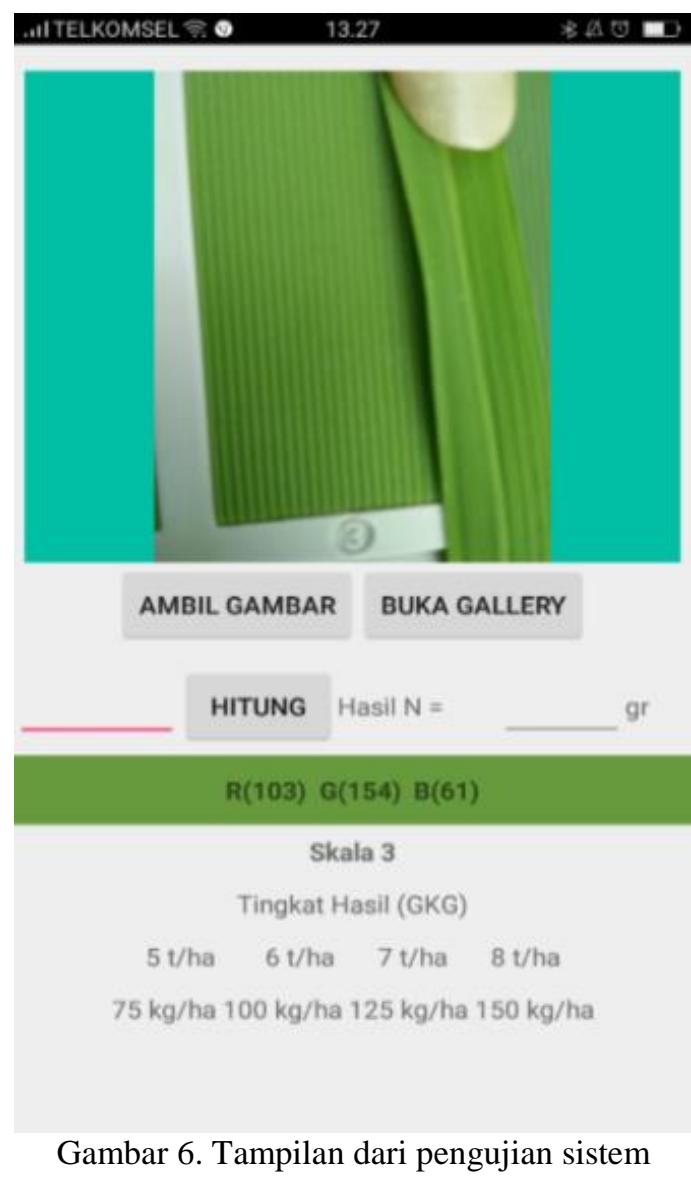

Gambar 6 merupakan hasil pengujian dari citra yang sudah diambil, setelah di tampilkan pada image view, selanjutnya ketuk pada layar smartphone untuk menampilkan nilai RGB dapat berserta warnanya, selanjutnya nilai RGB tersebut akan digolongkan ke dalam skala BWD seperti pada tulisan Skala 4 dan kemudian ditampilkan jumlah pupuk yang dianjurkan untuk digunakan menyesuaikan dengan tingkat hasil panen yang akan di inginkan.

\subsection{Hasil Pengujian Alat}

Pengujian alat dilakukan untuk mengetahui apakah aplikasi yang telah dibangun telah mampu bekerja dengan baik dan bisa akurat maupun mendekati hasil dari perhitungan manual. Pengujian manual dilakukan terhadap alat manual BWD, pengujian terhadap alat manual BWD dilakukan untuk mengetahui apakah nilai RGB dari aplikasi telah sesuai dengan skala BWD. Pengujian menggunakan 6 daun dari rumpun yang berbedabeda kemudian setiap satu daun akan mendapatkan 10 data atau diuji sebanyak 10 kali. Pengujian menggunakan aplikasi masih menggunakan 6 daun yang sama dengan daun yang digunakan pada pengujian secara manual dan setiap daun diambil 10 sampel nilai RGB sehingga total data hasil pengujian ada 60 data. Dari 60 data yang didapatkan dari pengujian selanjutnya akan dibandingkan antara data pengujian secara manual dan pengujian dengan aplikasi. Hasil pengukuran Kebutuhan Nitrogen Pada Tanaman Padi Berbasis Android disajikan pada Tabel 1. 
Tabel 1. Hasil pengujian alat

\begin{tabular}{|c|c|c|c|c|c|c|}
\hline \multirow{2}{*}{ No. } & \multirow{2}{*}{ Sampel } & \multicolumn{3}{|c|}{ Nilai RGB } & \multicolumn{2}{|c|}{ Keterangan } \\
\hline & & $\mathrm{R}$ & $\mathrm{G}$ & B & Manual & Aplikasi \\
\hline 1 & \multirow{10}{*}{ Daun 1} & 88 & 132 & 55 & Skala 3 & Skala 3 \\
\hline 2 & & 74 & 122 & 59 & Skala 3 & Skala 3 \\
\hline 3 & & 52 & 107 & 41 & Skala 3 & Skala 3 \\
\hline 4 & & 81 & 138 & 59 & Skala 3 & Skala 3 \\
\hline 5 & & 74 & 128 & 78 & Skala 3 & Skala 3 \\
\hline 6 & & 97 & 120 & 49 & Skala 3 & Skala 3 \\
\hline 7 & & 62 & 114 & 48 & Skala 3 & Skala 3 \\
\hline 8 & & 74 & 128 & 52 & Skala 3 & Skala 3 \\
\hline 9 & & 86 & 142 & 70 & Skala 3 & Skala 2 \\
\hline 10 & & 67 & 122 & 57 & Skala 3 & Skala 3 \\
\hline 1 & \multirow{10}{*}{ Daun 2} & 103 & 61 & 61 & Skala 3 & Skala 3 \\
\hline 2 & & 80 & 127 & 55 & Skala 3 & Skala 3 \\
\hline 3 & & 92 & 151 & 81 & Skala 3 & Skala 2 \\
\hline 4 & & 82 & 139 & 64 & Skala 3 & Skala 3 \\
\hline 5 & & 38 & 96 & 19 & Skala 3 & Skala 5 \\
\hline 6 & & 63 & 144 & 68 & Skala 3 & Skala 3 \\
\hline 7 & & 56 & 135 & 58 & Skala 3 & Skala 3 \\
\hline 8 & & 57 & 138 & 61 & Skala 3 & Skala 3 \\
\hline 9 & & 64 & 152 & 66 & Skala 3 & Skala 3 \\
\hline 10 & & 56 & 135 & 56 & Skala 3 & Skala 3 \\
\hline 1 & \multirow{10}{*}{ Daun 3} & 55 & 135 & 62 & Skala 3 & Skala 3 \\
\hline 2 & & 57 & 124 & 56 & Skala 3 & Skala 3 \\
\hline 3 & & 70 & 138 & 67 & Skala 3 & Skala 3 \\
\hline 4 & & 63 & 141 & 65 & Skala 3 & Skala 3 \\
\hline 5 & & 70 & 146 & 74 & Skala 3 & Skala 3 \\
\hline 6 & & 53 & 134 & 54 & Skala 3 & Skala 3 \\
\hline 7 & & 50 & 123 & 53 & Skala 3 & Skala 4 \\
\hline 8 & & 75 & 148 & 75 & Skala 3 & Skala 3 \\
\hline 9 & & 67 & 144 & 72 & Skala 3 & Skala 3 \\
\hline 10 & & 87 & 178 & 82 & Skala 3 & Skala 2 \\
\hline 1 & \multirow{10}{*}{ Daun 4} & 68 & 149 & 73 & Skala 3 & Skala 3 \\
\hline 2 & & 51 & 137 & 46 & Skala 3 & Skala 3 \\
\hline 3 & & 95 & 183 & 99 & Skala 3 & Skala 2 \\
\hline 4 & & 49 & 130 & 54 & Skala 3 & Skala 4 \\
\hline 5 & & 51 & 129 & 59 & Skala 3 & Skala 3 \\
\hline 6 & & 54 & 132 & 57 & Skala 3 & Skala 3 \\
\hline 7 & & 56 & 141 & 60 & Skala 3 & Skala 3 \\
\hline 8 & & 52 & 133 & 57 & Skala 3 & Skala 3 \\
\hline 9 & & 62 & 130 & 65 & Skala 3 & Skala 3 \\
\hline 10 & & 57 & 136 & 57 & Skala 3 & Skala 3 \\
\hline 1 & & 62 & 143 & 66 & Skala 3 & Skala 3 \\
\hline 2 & & 92 & 157 & 99 & Skala 3 & Skala 2 \\
\hline
\end{tabular}




\begin{tabular}{|c|c|c|c|c|c|c|}
\hline \multirow{2}{*}{ No. } & \multirow{7}{*}{$\begin{array}{l}\text { Sampel } \\
\text { Daun } 5\end{array}$} & \multicolumn{3}{|c|}{ Nilai RGB } & \multicolumn{2}{|c|}{ Keterangan } \\
\hline & & $\mathrm{R}$ & G & B & Manual & Aplikasi \\
\hline 3 & & 79 & 162 & 82 & Skala 3 & Skala 2 \\
\hline 4 & & 70 & 146 & 72 & Skala 3 & Skala 3 \\
\hline 5 & & 70 & 145 & 76 & Skala 3 & Skala 3 \\
\hline 6 & & 62 & 140 & 65 & Skala 3 & Skala 3 \\
\hline 7 & & 64 & 139 & 70 & Skala 3 & Skala 3 \\
\hline 8 & & 58 & 134 & 60 & Skala 3 & Skala 3 \\
\hline 9 & & 67 & 138 & 72 & Skala 3 & Skala 3 \\
\hline 10 & & 113 & 148 & 118 & Skala 3 & Skala 2 \\
\hline 1 & \multirow{10}{*}{ Daun 6} & 56 & 138 & 62 & Skala 3 & Skala 3 \\
\hline 2 & & 73 & 146 & 75 & Skala 3 & Skala 3 \\
\hline 3 & & 77 & 160 & 80 & Skala 3 & - \\
\hline 4 & & 81 & 154 & 81 & Skala 3 & Skala 2 \\
\hline 5 & & 57 & 124 & 57 & Skala 3 & Skala 3 \\
\hline 6 & & 61 & 134 & 65 & Skala 3 & Skala 3 \\
\hline 7 & & 65 & 140 & 65 & Skala 3 & Skala 3 \\
\hline 8 & & 40 & 110 & 38 & Skala 3 & Skala 4 \\
\hline 9 & & 55 & 125 & 55 & Skala 3 & Skala 3 \\
\hline 10 & & 62 & 135 & 66 & Skala 3 & Skala 3 \\
\hline
\end{tabular}

Tabel 1 merupakan hasil-hasil pengujian yang dilakukan, pengujian dengan dua acara, yaitu pengujian manual dan pengujian menggunakan aplikasi. Bertujuan untuk membandingkan hasil pengujian menggunakan manual menggunakan alat BWD dengan menggunakan aplikasi yang dirancang. Pengujian secara manual melibatkan 6 orang relawan, relawan akan melakukan pengujian menggunakan alat BWD. Pengujian menggunakan 6 daun dari rumpun yang berbeda-beda kemudian setiap satu daun akan mendapatkan 10 data atau diuji sebanyak 10 kali. Pengujian menggunakan aplikasi masih menggunakan 6 daun yang sama dengan daun yang digunakan pada pengujian secara manual dan setiap daun diambil 10 sampel nilai RGB sehingga total data hasil pengujian ada 60 data. Dari 60 data yang didapatkan dari pengujian selanjutnya akan dibandingkan antara data pengujian secara manual dan pengujian dengan aplikasi Pengukuran Kebutuhan Nitrogen Pada Tanaman Padi Berbasis Android.

Aplikasi yang dirancang saat ini belum dapat mengategorikan hasil di antara 2 skala sehingga hasil yang menyatakan skala 2 ataupun skala 3 dianggap benar. Dari data hasil pengujian yang didapat, 6 daun yang di uji menunjukkan skala 3, sehingga bisa disimpulkan bahwa hasil akhir pengujian adalah padi di lahan tersebut termasuk dalam skala 3 dan jumlah pupuk yang dianjurkan adalah $75 \mathrm{~kg} / \mathrm{ha}$ untuk tingkat hasil yang ingin dicapai adalah 5 ton/ha, $100 \mathrm{~kg} / \mathrm{ha}$ untuk tingkat hasil yang ingin dicapai 6 ton/ha, $125 \mathrm{~kg} / \mathrm{ha}$ untuk tingkat hasil 7 ton/ha, dan $150 \mathrm{~kg} / \mathrm{ha}$ untuk tingkat hasil yang ingin dicapai 8 ton/ha.

Kemudian dapat mengetahui berapa persentase error dari aplikasi yang telah dirancang dapat dihitung sebagai berikut. Diketahui nilai Pengukuran manual adalah 60 dan Nilai Pengukuran aplikasi adalah 47 sehingga

$$
\text { Error }=\frac{60-47}{60} \times 100=21,66 \%
$$

Dari perhitungan persentase error untuk pengujian menggunakan aplikasi didapatkan persenstase error sebesar 21,66\%. Tingkat akurasi dari hasil pengukuran menggunakan aplikasi dapat diukur dengan persamaan berikut. Diketahui jumlah data adalah 60 dan jumlah data benar adalah 47 sehingga

$$
\text { Akurasi }=\frac{47}{60} \times 100=78,33 \%
$$

Tingkat akurasi yang ditunjukkan oleh hasil pengukuran menggunakan aplikasi adalah 78,33\% dimana sebanyak 50 data menunjukkan hasil yang sama dengan hasil pengujian menggunakan alat BWD secara manual. Proses pengujian ini dilakukan selama 2 kali dalam hari yang berbeda, di waktu yang sama, yaitu di 
sore hari pukul 16.00 WIB di salah satu lahan persawahan Kecamatan Srandakan, Kabupaten Bantul dan dengan jenis padi yang digunakan dalam pengujian adalah Matonggang dengan usia $\pm 22-25$ hari setelah tanam.

\section{KESIMPULAN}

Setelah dilakukan pengujian terhadap Aplikasi Alat Uji Kandungan Nitrogen Dalam Daun Padi Berbasis Aplikasi Android dalam penelitian ini menggunakan aplikasi Android Studio dimulai dari perancangan GUI menggunakan tampilan Card View untuk menampilkan tombol-tombol di halaman utama dan keseluruhan aplikasi terbagi menjadi beberapa class yaitu class Home.java sebagai halaman utama, class camera.java sebagai halaman pengujian, class Petunjuk.java sebagai halaman petunjuk penggunaan aplikasi dan class Tentang.java sebagai halaman informasi tentang aplikasi kemudian metode yang digunakan yaitu metode OnTouch Motiont Event yang dimiliki aplikasi Android Studio. Hasil pengujian yang telah dilakukan pada 6 sampel daun padi dengan 60 sampel data nilai RGB menghasilkan tingkat akurasi menggunakan aplikasi sebesar 78,33\% dan 21,66\% sisanya merupakan nilai error. Dan cara menghitung luas lahan diperoleh hasil kebutuhan urea per tanaman dalam 1 ha adalah $120 \mathrm{~kg}$ dimana dalam tabel BWD menunjukkan nilai warna daun berada pada skala 2-3 dan membutuhkan takaran urea 100 yang diperkirakan mendapatkan tingkat hasil $6 \mathrm{t} / \mathrm{ha}$.

\section{UCAPAN TERIMA KASIH}

Terima kasih tak lupa penulis ucapkan kepada editor dan reviewer atas semua saran dan masukkan serta kepada semua pihak yang terkait dalam penyelesaian jurnal ini. Semoga kebaikan yang telah diberikan kepada penulis dapat menjadi amal ibadah dengan balasan pahala dari Allah SWT. Penulis mengharapkan agar tugas akhir ini dapat dimanfaatkan dengan sebaik-baiknya guna menambah ilmu pengetahuan khususnya bagi para pembaca pada umumnya.

\section{REFERENSI}

[1] I. N. Y. Wijana, S. Gede, and G. M. Adnyana, "Aplikasi Jenis Pupuk Organik pada Tanaman Padi Sistem Pertanian Organik,” E-Jurnal Agroekoteknologi Trop., vol. 1, no. 2, pp. 98-106, 2012. Online

[2] A. R. T. Saputra, L. Rahmawati, D. Budianta, and S. J. Priatna, "Serapan Nitrogen pada Pertumbuhan Padi (Oryza Sativa L) dengan Pemberian Biochar di Lahan Rawa Lebak Nitrogen Uptake in Growth of Rice (Oryza Sativa L.) by Applying Biochar in Peat Swamp,” Pros. Semin. Nas. Lahan Suboptimal, pp. 65-73, 2016. Online

[3] T. Triadiati, A. Pratama, and S. Abdulrachman, "Pertumbuhan dan Efisiensi Penggunaan Nitrogen pada Padi (Oryza sativa L.) Dengan Pemberian Pupuk Urea yang Berbeda," Buletin Anatomi dan Fisiologi, vol. 20, no. 2, pp. 1-14, Apr. 2013. https://doi.org/10.14710/baf.v20i2.4767

[4] E. Tando, "Upaya Efisiensi Dan Peningkatan Ketersediaan Nitrogen Dalam Tanah Serta Serapan Nitrogen Pada Tanaman Padi Sawah (Oryza Sativa L.)," Buana Sains, vol. 18, no. 2, 2018. DOI: https://doi.org/10.33366/bs.v18i2.1190

[5] S. M. Bagshaw and R. Bellomo, "the Influence of Knowledge Management on," Curr. Opin. Crit. Care, vol. 13, no. 5, pp. 541-548, 2017. DOI: https://doi.org/10.1097/MCC.0b013e3282e2a978

[6] R. L. A. Abu, Z. Basri, U. Made, "Respon Pertumbuhan Dan Hasil Tanaman Padi (Oryza Sativa L.) Terhadap Kebutuhan Nitrogen Menggunakan Bagan Warna Daun," Agroland, vol. 24, no. 2, 2017. Online

[7] A. Domiah, J. Januar. "Studi Komparatif Usahatani Padi Semi Organik Dan Konvensional Di Desa Watukebo Kecamatan Blimbingsari Kabupaten Banyuwangi," JSEP (Journal of Social and Agricultural Economics), vol. 11, no. 3, 56-65, 2018. DOI: https://doi.org/10.19184/jsep.v11i3.9146

[8] B. E. Cahyono, A. T. Nugroho, and A. Arifilla, "Analisis usia tanaman padi berdasarkan nilai NDVI menggunakan citra LANDSAT 8," Jurnal Teras Fisika: Teori, Modeling, dan Aplikasi Fisika, vol. 2, no.1, pp. 9-13, 2019. DOI: https://doi.org/10.20884/1.jtf.2019.2.1.1245

[9] A. Shankar, R. K. Gupta, and B. Singh," Establishing indicator leaf and its threshold values for need based nitrogen management using chlorophyll meter and leaf color chart in Bt cotton," Journal of Plant Nutrition, vol. 42, no. 2 pp. 186-201, 2019. DOI: https://doi.org/10.1080/01904167.2018.1551492

[10] E. Murniyasih and luluk suryani," The Application Of Learning Vector Quantization Method For Identifying The Rice Disease Based On The Shape Of Leaf Spot”, Jurnal Electro Luceat (JEL), vol. 6, no. 1, pp. 28-35, Jul. 2020. DOI: https://doi.org/10.32531/jelekn.v6i1.190

[11] S. A. Akbar, A. Yudhana, "Prototipe Tabung Semprot Pupuk Cair Berbasis Wahana Quadcopter bagi Lahan Pertanian Tanaman Padi," Jurnal Ecotipe, vol. 3, no. 2, hlm. 26-30, 2016. DOI: https://doi.org/10.33019/ecotipe.v3i2.22

[12] A. Yudhana, H. S. Purnama, M. Ramadhani, A. C. Subrata," Otomasi dan Instrumentasi untuk Smart Farming dan Smart Glove," Eprint UAD, 2018. Online

[13] A. Yudhana, Sunardi, S. Saifullah, "Segmentation Comparing Eggs Watermarking Image and Original Image," Buletin of Electrical Engineering and Informatics, vol. 6, No. 1, pp. 47-53, 2017. DOI: https://doi.org/10.11591/eei.v6i1.595

[14] E. B. Setiawan and R. Herdianto," Penggunaan Smartphone Android sebagai Alat Analisis Kebutuhan Kandungan Nitrogen pada Tanaman Padi," JNTETI, vol. 7, no. 3, 2018. DOI: http://dx.doi.org/10.22146/jnteti.v7i3.435 


\section{BIOGRAFI PENULIS}

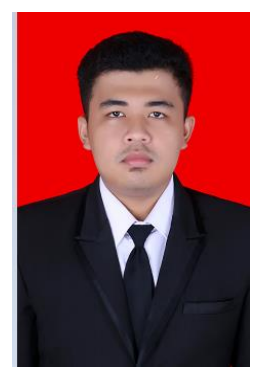

Muhamad darso

Lahir di Rimbo Bujang tanggal 15 Desember 1995. . Menyelesaikan pendidikan S1 Teknik Ekektro di Universitas Ahmad Dahlan Yogyakarta.

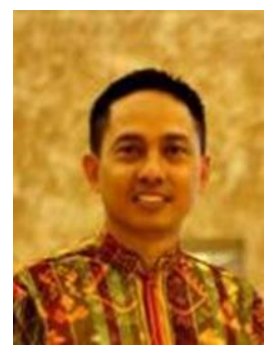

\section{Anton Yudhana}

Lahir Purworejo, 18 Agustus 1976. Menyesaikan penidikan S1 Teknik Elektro di Institut Teknologi Sepuluh Nopember Surabaya, S2 Teknik Elektro di Universitas Gajah Mada Yogyakarta, S3 Teknik Elektro di Universitas Teknologi Malaysia. Bidang keahlian: High Frequency \& Radio Communication. 